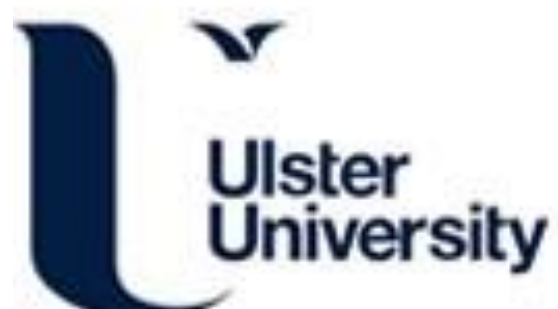

The Relationship between Youth Identity and Spatial Perception within the Context of Religious Architecture in Northern Ireland.

McPhillips, K., \& Russell, J. (2011). The Relationship between Youth Identity and Spatial Perception within the Context of Religious Architecture in Northern Ireland. International Journal of the Constructed Environment, 1 , 97-114.

Link to publication record in Ulster University Research Portal

Published in:

International Journal of the Constructed Environment

Publication Status:

Published (in print/issue): 25/05/2011

\section{Document Version}

Publisher's PDF, also known as Version of record

\section{General rights}

Copyright for the publications made accessible via Ulster University's Research Portal is retained by the author(s) and / or other copyright owners and it is a condition of accessing these publications that users recognise and abide by the legal requirements associated with these rights.

\section{Take down policy}

The Research Portal is Ulster University's institutional repository that provides access to Ulster's research outputs. Every effort has been made to ensure that content in the Research Portal does not infringe any person's rights, or applicable UK laws. If you discover content in the Research Portal that you believe breaches copyright or violates any law, please contact pure-support@ulster.ac.uk. 
THE INTERNATIONAL

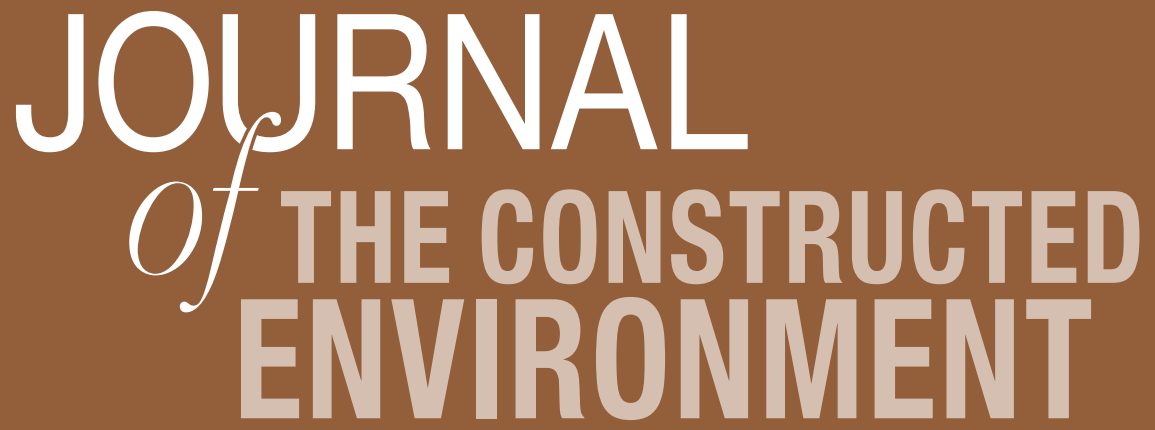

Volume 1, Number 1

The Relationship between Youth Identity and Spatial Perception within the Context of Religious Architecture in Northern Ireland

Karen McPhillips and Jenny Russell 
THE INTERNATIONAL JOURNAL OF THE CONSTRUCTED ENVIRONMENT

http://constructedenvironment.com/Journal/

First published in 2011 in Champaign, Illinois, USA

by Common Ground Publishing LLC

www.CommonGroundPublishing.com

ISSN: $2152-7857$

(C) 2011 (individual papers), the author(s)

(c) 2011 (selection and editorial matter) Common Ground

All rights reserved. Apart from fair dealing for the purposes of study, research, criticism or review as permitted under the applicable copyright legislation, no part of this work may be reproduced by any process without written permission from the publisher. For permissions and other inquiries, please contact

<cg-support@commongroundpublishing.com>.

THE INTERNATIONAL JOURNAL OF THE CONSTRUCTED ENVIRONMENT is peerreviewed, supported by rigorous processes of criterion-referenced article ranking and qualitative commentary, ensuring that only intellectual work of the greatest substance and highest significance is published.

Typeset in Common Ground Markup Language using CGPublisher multichannel typesetting system

http://www.commongroundpublishing.com/software/ 


\title{
The Relationship between Youth Identity and Spatial Perception within the Context of Religious Architecture in Northern Ireland
}

\author{
Karen McPhillips, University of Ulster, UK \\ Jenny Russell, University of Ulster, UK
}

\begin{abstract}
The relationship between religious buildings and the shaping of young people's identities is one which has received little investigation. Northern Ireland is a region which has experienced a religious divide for many years and provides an interesting setting on which to examine concepts associated with religion, youth, place, and spatial perception of architecture as an aspect of identity. Religion is an important part of life in Northern Ireland and religious buildings have played a vital role in shaping modern society by providing spaces for young people to learn about their faith and culture. This study investigated how young people from different religious backgrounds perceived certain elements of place, religion and identity, in particular, how they interpreted and negotiated the spatial layout of religious buildings and perceived the relationship between the space and the religion itself. The study endeavoured to promote the cross cultural understanding of young people's perceptions of religion and architecture and provide further clarity into the cultural and social distinctions between young teenagers of conflicting religions. An insight was gained through the analysis of non-textual material such as drawings and art-work developed from young people. This paper lays out the key findings of this study, identifying architectural concepts that are fundamental to the production of different religious places in Northern Ireland and examines the impacts of religious places, through spatial experience, and their conceptual architectural configurations, on young people's perceptions, ideas and understanding of religion. The main religions of Northern Ireland, Catholicism and Protestantism, along with the minority religions of Judaism, Islam and Hinduism, were examined.
\end{abstract}

Keywords: Religious Architecture, Spatial Perception, Identity, Youth

\section{Introduction}

$\mathrm{N}$

ORTHERN IRELAND AND its capital city of Belfast provide an interesting setting on which to examine religious architecture as an aspect of identity. Belfast's religious buildings often reflect decades of society-wide sectarian conflict (Russell, 2004). Conflict from the late 1960s to 1998, has marked Northern Ireland as an unusual Christian place in which Protestantism and Catholicism dominate in Belfast, representing $95.8 \%$ of the city population. Religion still plays an important role in shaping the social behaviour of many communities, a fact reflected in statistics indicating a significant number of regular churchgoers in Northern Ireland (45\%) compared to 18\% in Scotland; $14 \%$ in England and 12\% in Wales (Ashworth and Farthing, 2007). Little information is available on church attendance rates for young people aged 16 and below. Despite the lack of statistical age related data, religious buildings in Northern Ireland play a unique and vital role in

The International Journal of the Constructed Environment

Volume 1, Number 1, 2011, http://constructedenvironment.com/Journal/, ISSN 2152-7857 
shaping modern society and providing spaces for young people to learn about their faith and culture.

In Belfast, religious spaces are generally 'church spaces', which are often historically used to interpret local identity and to forge politically useful connections to the past (Vale, 1999). In Northern Ireland, religious buildings have become a symbolic connection between territory and identity which result in the surrounding space becoming highly signified. Unlike other typologies, the visual impacts of church architecture as well as their locales have strongly influenced the shaping of the built environment in Northern Ireland, and hence the sense of belonging (Mitchell, 2006). Interestingly, as the demography in Belfast changes with evident growth in catholic communities and matching decline in protestant populations, churches are now located in opposing communities.

The two main religions, Protestant British and Roman Catholic Irish, were included in this study along with minority religions of Islam, Hindu and Judaism. These minority religions account for a mere $0.78 \%$ of the Belfast population, and are represented by a single religious building. The Protestant, Roman Catholic and Synagogue are purpose built; however, the Islamic Centre and Indian Community Centre are located in converted/adapted buildings.

This project aimed to examine issues of religious architecture as an aspect of identity in young people. More specifically the research aimed to identify the architectural concepts that are fundamental to the production of different religious places in Northern Ireland; explore the core values in different religions that lead to the adoption of certain spatial configurations and finally, examine the impacts of religious places and their conceptual architectural configurations, on youth's perceptions, ideas and understanding of religion.

\section{Literature}

Although much research has been conducted into the impact of division and conflict on children's and teenage identities, there has not, as yet, been specific research into the role that the physicality of religious architecture and buildings have to play in forming the identity of youth in Northern Ireland. While previous research regarding the assessment of children's perceptions of space has offered insight into the environmental needs and behaviours of children and young people, they are still seen as an outsider group in society (Matthews, 1995). The majority of youth-centred spatial research is given to the perception of external environments, both rural and urban and specific architectural research relating to the larger picture of the urban environment. There is little relating to the specifics of spatial design with regard to the user, particularly within the focused area of religious space. Some studies have been conducted with children in regards to their most personal and favourite places (Korpela, Kytta and Hartig 2002; Malinowski and Thurber, 1996) but little within specific and complete architectural examples.

This study focused on a number of key literature areas relating to youth and identity; (1) religion and social development, (2) the political conflict in Northern Ireland and finally (3) the influence of architecture and understanding of space.

In terms of religion and social development; the field of youth development is increasing and religion and spirituality are seen to be influential sources of developmental progress (King, 2003; Benson, Roehlkepartain and Rude, 2003; Kerestes and Youniss, 2002). Studies suggest that religion can have a positive effect on young people and can act as a support to encourage positive behaviour and attitude (Wagener et al, 2003; Donahue and Benson, 1995). 
Historically, Erikson $(1964,1968)$ raises the issue that the development of identity is crucial to the positive development of young people and to their ability to make a positive contribution to society, which is also evidenced by other studies which cite engagement in moral activities as informants of identity (Lerner, Dowling and Anderson, 2003; Furrow, King and White, 2004). Despite the existing research concluding that religion is of fundamental importance to the positive development of young people, little research explores the role of religion and development in the context of a tensioned society.

In terms of Northern Ireland, a plethora of research has been conducted into the impact the political violence and religious divide has held on the identity of children and young teenagers of the Protestant and Roman Catholic faiths. Studies have shown that children are much more susceptible to be influenced by their physical and visual surroundings than adults (Sanoff, 2000). Trew (2004) summarises early attempts to study children's understanding of sectarian divisions as focusing on children's developing ability to discriminate between Catholic and Protestant groups (Cairns, 1987). Recent research on sectarianism, children, and community relations from a sociological perspective (Connolly, 2003; Connolly and Healy, 2003; Connolly, Smith, \& Kelly, 2002) has widened the focus of study to include the child's developing awareness of ritualized events and symbols that mark group identities. The research collectively shows that children and teenagers are undoubtedly affected by the political tension in Northern Ireland. The continual process of separation and segregation in housing and education (Cairns and Hewstone, 2002) together with the constant visual reminders of a religious/political divide have clearly impacted on children's and teenage identities (Cairns, 1987).

With reference to the final theme, architecture and space; studies have shown that in a contested space such as Northern Ireland religious spaces are often identified as 'significant' providing stability and security to local identity (Brown and Perkins, 1992). Whilst the characteristics of place in Northern Ireland can be considered to inspire and cultivate community and identity; studies also show that a person's connection to place is not solely reliant on the qualities of place but that they can also be learned through the process of religious socialization. This is defined by (Mazumdar and Mazumdar, 2004) to be the influence of parents, educators and peers with the larger community of believers. The connection young people have to religious spaces in Northern Ireland is, however, by in large unknown.

Another relevant area of literature relates to the phenomenological approach to architecture; in particular experience and social use of space. Many philosophers such as Bachelard (1969), Norberg-Schulz (1972) and Foucault (1972) have explored the concept surrounding the human experience of architecture and space. As described by Bachelard (1969) 'A house that has been experienced is not an inert box. Inhabited space transcends geometrical space'. Although it is beyond the remit of this paper to focus specifically on such aspects of architectural theory, it is important to note that personal experience is an essential part of architecture and space.

\section{Methodology}

The methodological approach was two-fold. Firstly, the identification of religious buildings and architectural concepts, and second the recruitment of young people along with the development of workshops to allow the youth to experience each religious space.

Drawing and self directed photography were used in this research to elicit information particularly in relation to the environment. It has been found that children and young people 
will often draw that which is important to them and leave out that which is not (Butterworth, 1977). To draw is one of the means by which young people express their inner-self and can be interpreted as a method of communication, which is often the case in sociological and psychological research. They draw what they know in their own style and thus their perceptions, emotions, sensibilities, and motor functions, together with the factor of social experience are all added to the picture that is drawn on the paper (Kitahara and Matsuishi, 2006).

By combining the described drawings of the young people and their own self-directed photography with observations of behaviour and informal interviews conducted through 'experiential walkabouts' of each building, it was hoped that the techniques would be as youth-friendly as possible, to enable analysis to be implemented to the highest standard.

\section{Religious Buildings}

The religious spaces were selected on the basis of locality or examples of excellence. In the case of the minority religions, there was only one available space of worship and this was used. The buildings used for this study included:

- Catholic: St Malachy's Catholic Church

- Protestant/Church of Ireland: St George's Church of Ireland

- Judaism: Belfast Synagogue

- Hindi: Indian Community Centre, which incorporates a Hindi temple within the building

- Islam: Belfast Islamic Centre: A converted Georgian residential property which uses the first floor as the mosque.

\section{Architectural Concepts}

Tracing through the configuration and shaping of religious spaces, a set of indicators of architectural concepts for each religion was identified (Table 1). These indicators best represented the important elements and processes with each religious building, therefore enabling a basis for comparison.

Table 1: Architectural Concepts

\begin{tabular}{|l|l|}
\hline $\begin{array}{l}\text { Architectural } \\
\text { Feature }\end{array}$ & Description \\
\hline Spatial Dynamics & $\begin{array}{l}\text { Spatial dynamics refers to the hierarchy, components and orientation } \\
\text { of space within a building. }\end{array}$ \\
\hline Purity & $\begin{array}{l}\text { Purity refers to the gender differences and distinctions between the } \\
\text { role of adults, children, gender and social classification. It also refers } \\
\text { to preparation before prayer. }\end{array}$ \\
\hline Rituals and Symbols & $\begin{array}{l}\text { Rituals and symbols refer to religious activity and symbology connec- } \\
\text { ted to and conducted within religious buildings. }\end{array}$ \\
\hline Tolerance & $\begin{array}{l}\text { Tolerance refers to the condition of accepting or permitting other re- } \\
\text { ligious beliefs and practices which disagree with ones own. }\end{array}$ \\
\hline
\end{tabular}




\section{Recruitment}

The recruitment of young people took place through the selection of willing participants from each of the congregations approached. A total of 19 young people covering three religious backgrounds were involved in the workshops. The participants ranged between 11-14 years old. All the participating youths attended their place of worship at least once a week. $73 \%$ were from the Roman Catholic faith, 16\% Protestant faith and 11\% from the Hindu faith.

\section{Workshops}

By employing a multi-method approach to a series of religious buildings, of which the specific methodologies are, in essence, youth-friendly, this research questioned initial presumptions prior to each visit, experiences while in each religious space and views following each visit. The studies were fundamentally qualitative but as "real-world" tests it was important that the buildings used were chosen from their immediate surroundings and thus buildings from Belfast were selected. It was of fundamental importance that the young people were regarded with having the ability to express through drawings their comprehension of physical space, and ultimately that they became knowledgeable subjects of their own experiences of space.

The workshop tours encompassed visual, textural, oral and audio processes: The youth's were escorted on a 'conversational walkabout' around the building by volunteers and asked a series of questions regarding their opinions of the space. The young people were asked to photograph anything which they thought was of relevance and on conclusion of the tour asked to draw the space, highlighting any important places or elements within the building.

At the completion of the tours a responsive workshop was conducted. During the responsive workshops the participants were asked to reflect on each space they had visited. They were shown pictures of each building and ask to draw a plan of the space. With coloured pen they were asked to code the drawing to consider gender, important rituals undertaken before entering the space, the location of the holy book, the location of the important spaces and the spaces that they felt they could not stand or enter. Through this method each drawing was analysed to identify the important elements in each space. Each colour represented a key architectural feature identified through the literature review (Table 1).

\section{Data Analysis}

The data was analyzed through the development of a series of comparative studies, tabling the experience of the youth participants of the key architectural concepts in relation to their religious background. Regarding their drawings and photographs, a section of analysis was dedicated to addressing this evidence purely and objectively as representations of space, through the consideration of the drawings by means of overall pattern; drawing method; scale; and orientation and certain key points highlighted, in order to contextualize the case study analysis in the basis of representation. The data was analysed in three sections: expectations, on-site experience and responsive actions which are based on a series of questions that the young people were asked after the visit relating to the architectural concepts. A series 
of matrices was then developed to record information regarding each of the architectural concepts in each drawing and set of photographs for each child.

\section{St George's Anglican Church}

St Georges Church is the oldest Anglican Church in use in the city of Belfast. Opened in 1816 , the Church was designed by John Bowden of Dublin and is an excellent example of the classical style of architecture that was fashionable in the opening decades of the $19^{\text {th }}$ century. St George's Church follows a classical sacramental style encompassing a spatial composition to include a longitudinal nave and chancel. This spatial pattern of the church enables the ritual of processions of various kinds from one space to the other. The focal point of the church is the altar, the place of sacrament to which the longitudinal space leads (Kieckhefer, 2004) (figure 1).

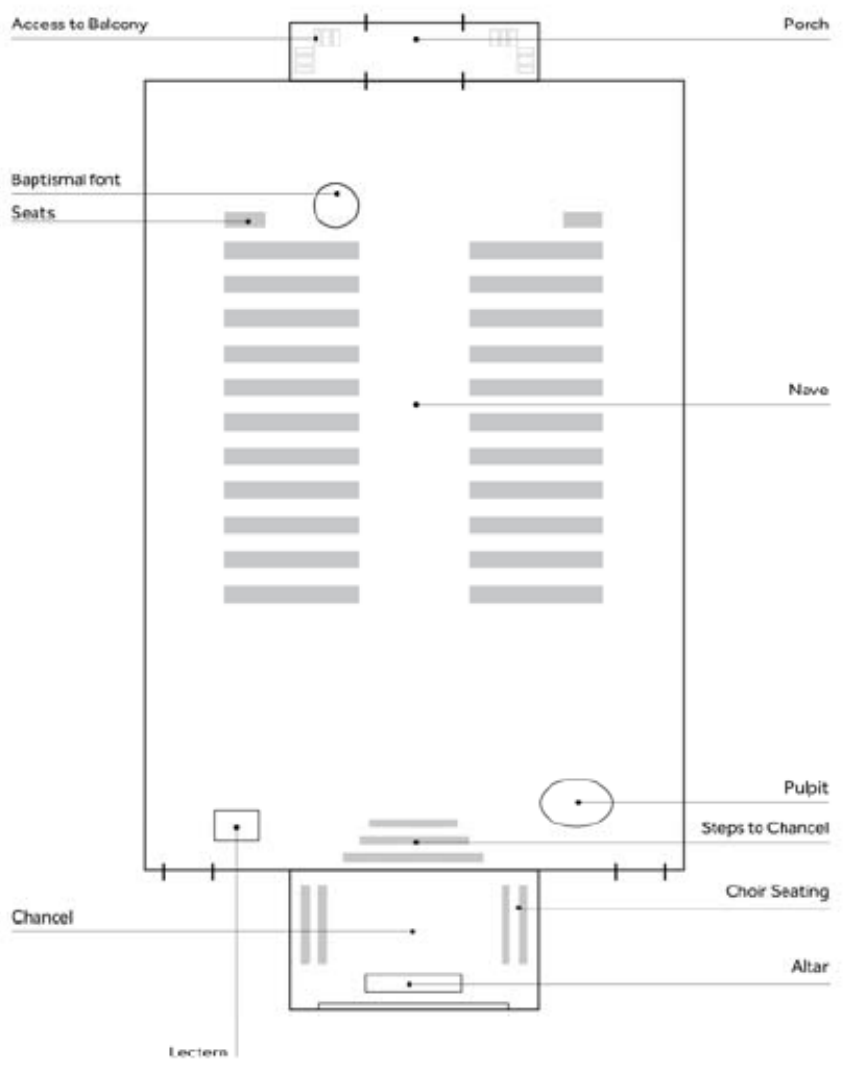

Figure 1: Spatial Representation of St George's Anglican Church

Before visiting the church, the teenagers were asked what they expected a protestant church to look like. The majority envisaged a plain building with a pointed/spired roof, cross and stained glass windows (figure 2). Some negative perceptions of the Protestant faith filtered through from the Catholic youth. These were represented by statements of difference for 
example when asked 'what do you expect a protestant church to look like', they responded by stating that they believed Protestants to worship only one god, and that they had no Jesus on the cross. They provided little information on what they thought the actual building would look like and choose to simply reflect on the perceived differences to the Catholic Church.

On visiting the building some of the young people commented on that fact that it did not look like a church. The young people choose to enter the main body of the space immediately and not explore the external area. Once inside, the space as a whole was generally not considered with the exception of one child who was very familiar with St George's church. The teenagers focused more on objects or elements of the space; specifically the altar, choir screen, stained glass windows, eagle shaped lectern, pulpit and cross. A focus on text was also evident with many young people attempting to copy the banner and words around the altar (figure 3).

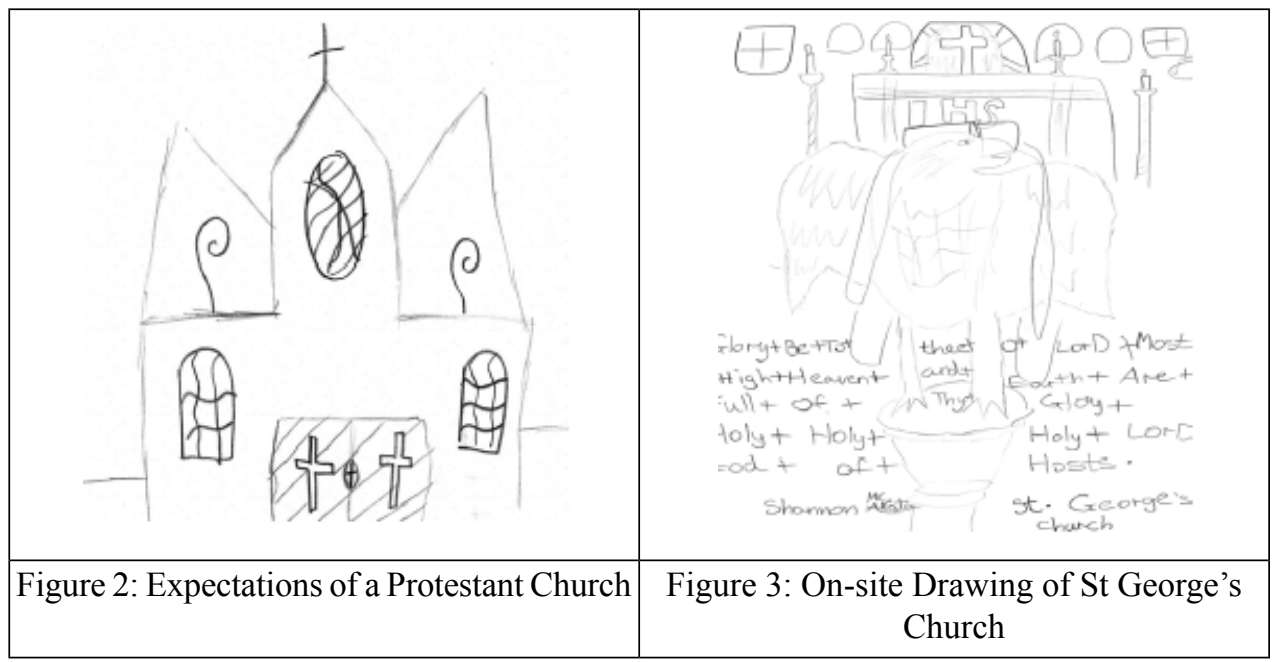

During the responsive workshop session the majority of young people provided a division of spaces to include the porch, nave and chancel (figure 4). The elements within the chancel were given priority. However, in a number of drawings the nave space was only represented by the arrangements of the pews. The important objects identified included the altar, eagle lectern, choir stalls, pulpit, organ and chairs for ministers. Everyone held an understanding that seating was of mixed gender with no hierarchy. The lectern and pulpit were correctly identified as the area for the bible and the chancel area as a restricted space in which not to stand. 


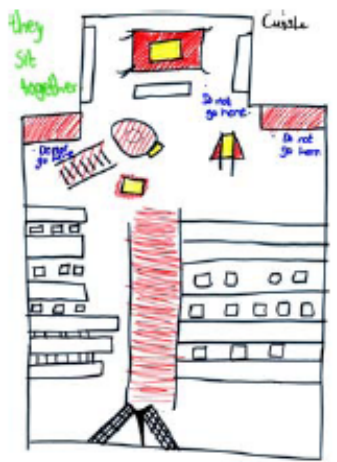

Figure 4: Youth Reflection Drawing of St Georges Church

\section{St Malachy's Roman Catholic Church}

St Malachy's Roman Catholic Church is the third oldest Catholic Church in the city of Belfast, and was first opened in 1884. The church was designed by Thomas Jackson of Waterford and it was designed in the ecclesiastical style of the Tudor period. The Church is similar to St George's in that it is considered a classical sacramental style church with a porch, nave and chancel (figure 5). The majority of young people who visited the Catholic Church imagined it to be similar in style to the Protestant church with the exception that it may be brighter, lighter and more decorative. Interestingly, the majority of the youth who associated positive type words with the building belonged to that faith.

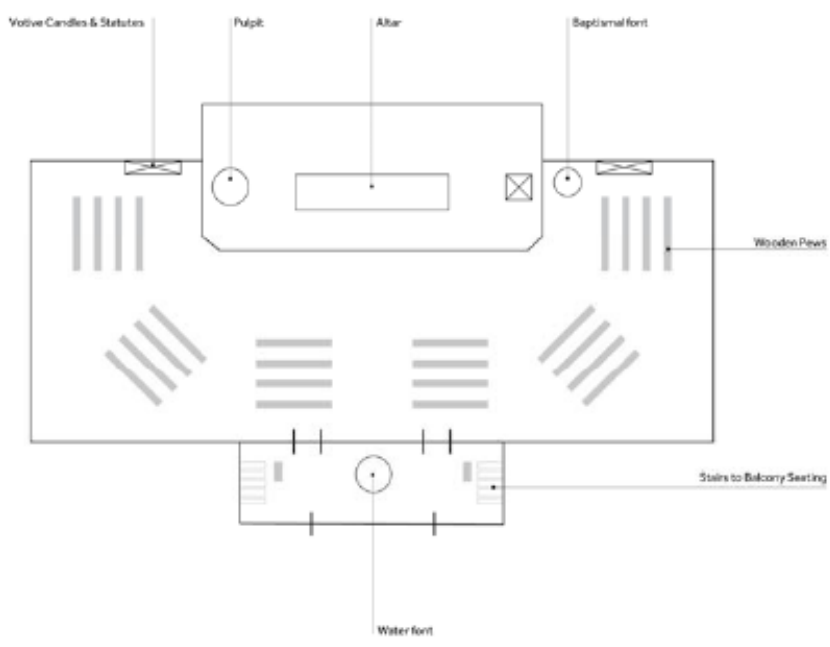

Figure 5: Spatial Representation of St Malachy's Church

During the visit, drawings of the Catholic Church were similar in nature to those of St George's as they focused mostly on the altar and sanctuary. The teenagers familiar with the space choose to draw the perspective from the altar and focused on the seating area. Interestingly, one of the key elements selected by these young people was the clock (figure 6). In 
most cases this object was also over emphasised in scale. Those young people who were viewing the space for the first time focused mostly on specific elements such as the altar and pulpit.

During the responsive session the youth drew a basic rectangular shape to outline the boundary of church space. The altar, pulpit and main sanctuary space along with balcony and seating provided an overview of the 'remembered' key elements within the space. The seating area was considered by all to be mixed and the ritual of blessing with holy water before entering the church was noted as essential preparation by the Catholic teenagers. Young people of other faiths also picked up on this ritual. The pulpit was correctly considered the location of the bible and it was apparent to all that the sanctuary area was significant (figure 7).

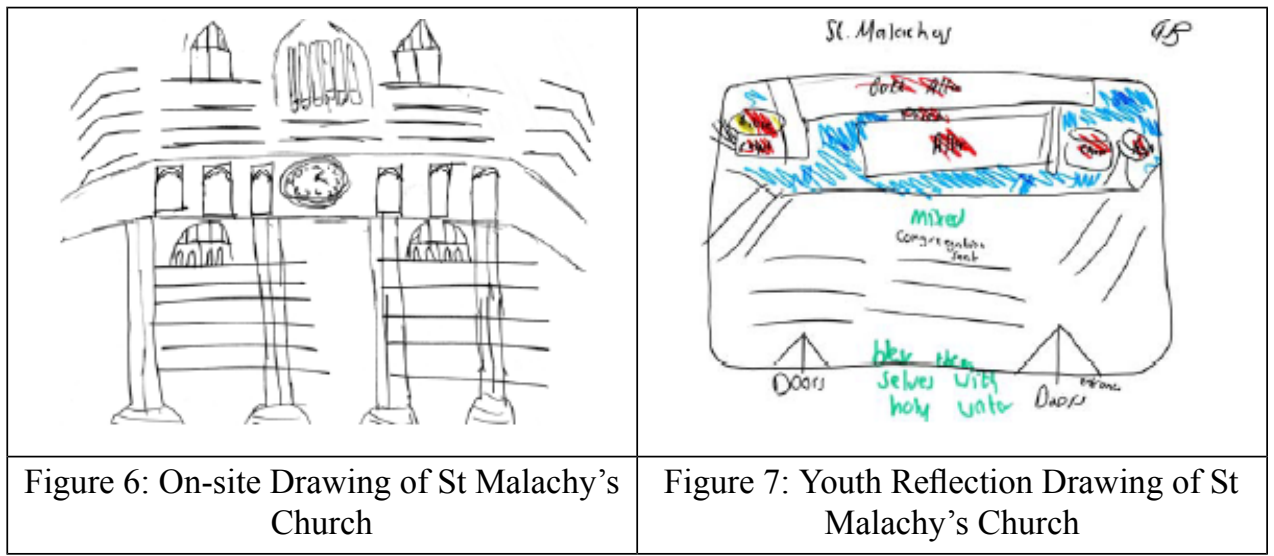

\section{Hindu Temple}

The Temple, located within a former Methodist church, was designed by W.H. Lynn in Gothic Revival style. The Indian Community Centre resides on the left hand side of the building, opposite the nave, which includes the lecture hall (figure 8). The majority of young people envisaged a temple to be a building composed of steeples or domes. The shapes of the buildings were considered more dynamic than the linear Christian church pattern previously drawn. More arches and points were introduced along with a representation of people praying on their knees or on mats. A number of teenagers associated a temple with an elephant form and many also interpreted the building to be located in a warm sunny environment i.e. the depiction of sun and palm trees (figure 9). 


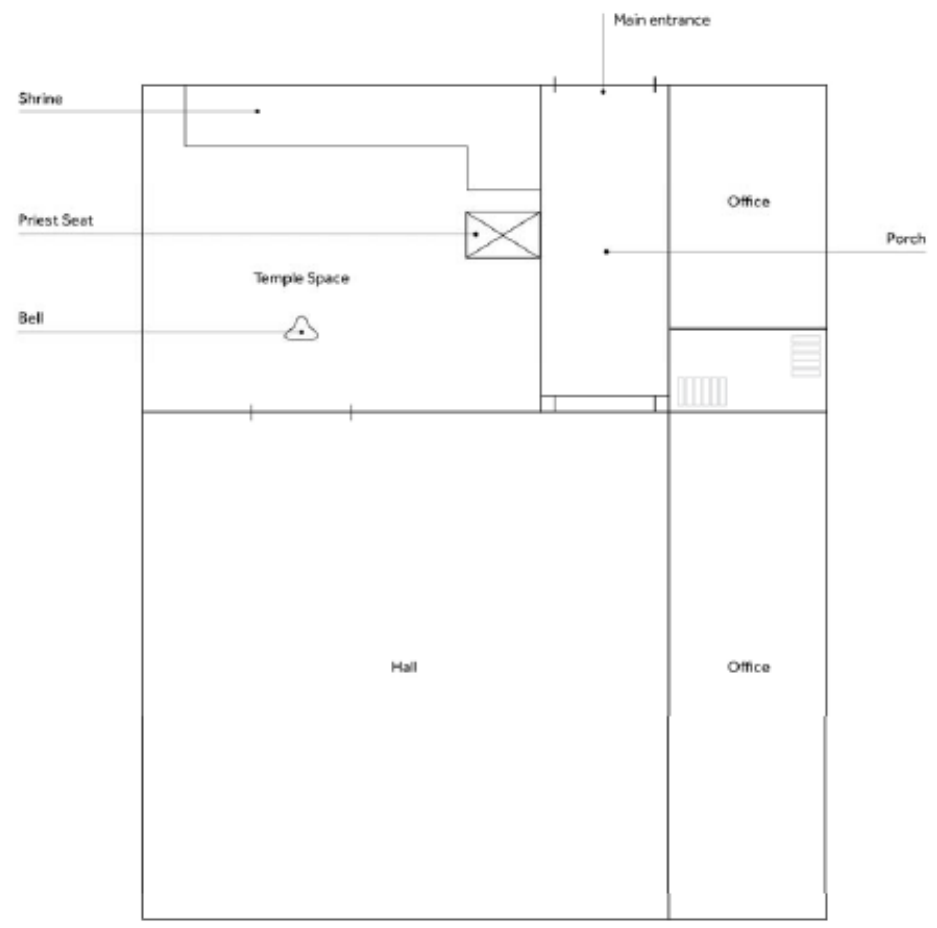

Figure 8: Spatial Representation of the Hindu Temple

During the site visit, the majority of teenagers focused on individual elements and images rather than anything complete. The shrine was very detailed and most of the drawings selected one section of the shrine incorporating some images or idols of the deity and associated objects. Some young people drew elements which appeared most familiar to them i.e. donation box. Only a few young people noticed specific details of the idols such as the placement of the raised hands.

On reflection during the responsive workshop, the majority of young people drew a basic rectangular shape as an outline of the temple space and included the important elements of the shrine, idols, priest's seat and bell. Some teenagers choose to focus on one element of the shrine and on offering objects instead of attempting to represent the entire space. Many also provided a representation of a mat in the centre of the room despite the fact that one did not exist.

All young people noted that men and women share the space and that shoes must be removed before entering the temple space. Some young people separated the men and women in the space into distinct areas; however, the majority had just visited the synagogue and could have been influenced by the issue of gender separation. No specific holy book or object was identified within the space. The majority of young people also interpreted that people sit facing the shrine and movement around the room is flexible in any direction. It was felt that the shrine and priests seat were the two key areas where they could not enter (figure $10)$. 


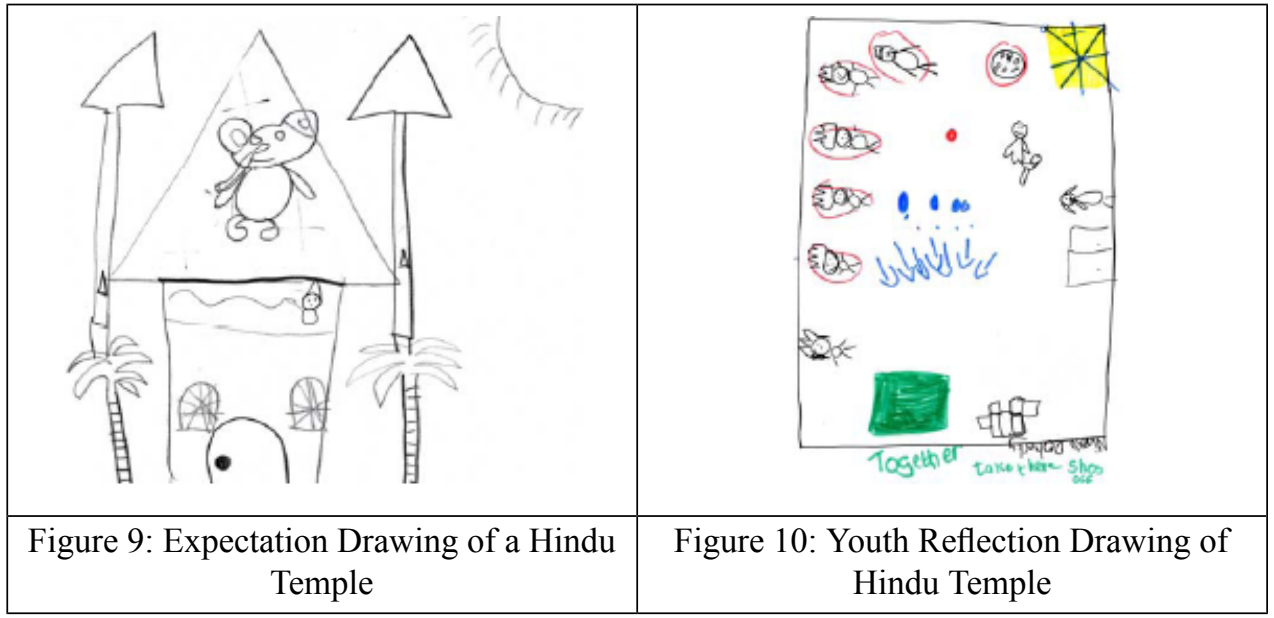

\section{Synagogue}

The Belfast Synagogue is circular in form, with no balcony for women but a raised platform on either side (figure 11). The majority of teenagers held no clear visual ideas about the appearance of a Synagogue. One Catholic child had stated that she had recently studied the Jewish faith at school and was therefore able to provide a number of key words associated with the religion but unfortunately no tangible drawings were produced. Some interesting preconceptions included that people would be kneeling.

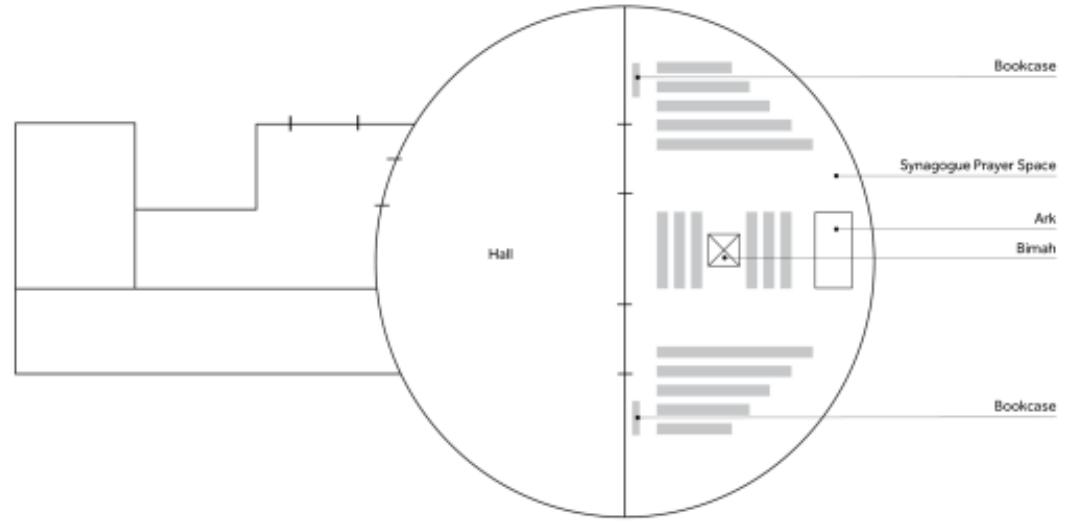

Figure 11: Spatial Representation of Belfast Synagogue

During the visit, the youth focused on the symbology of the space and drew elements such as the Star of David, Candle Stick, Hebrew lettering and doors to the Torah (figure 12). The seating plan was represented with a series of lines and concerns were raised through text about the separation of men and women.

As part of the responsive session, the majority of young people drew a basic rectangular shape with some providing an interpretation of a hexagonal shape influenced by the Star of David pattern evident on the roof. The central space (Bimah) and two tiered seating layout 
was well represented as spaces of importance. The plinth at the front of the room containing a lectern and candlesticks (Menorah) were also identified as essential elements. The separation of men and women was noted by all teenagers however, the organisation of men on the lower level and women on the raised level was sometimes misinterpreted. The central platform area (Bimah) was considered the most likely position for a holy book with the smaller lectern close to the doors of the torah also highlighted. Most of the young people felt that the congregation should face the central platform. The direction the Rabbi then faced was not addressed but confusion over the positioning of the lectern on the plinth close to the Torah was raised in a number of drawings (figure 13).

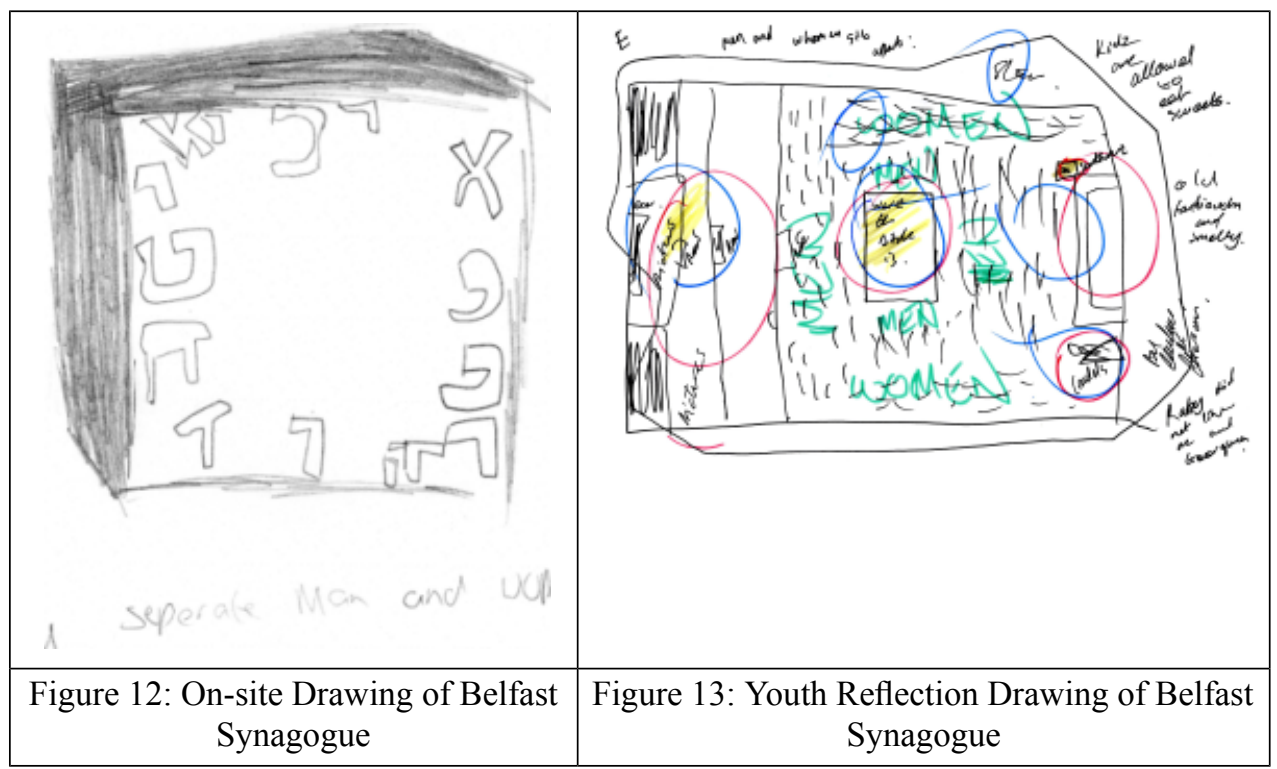

\section{Islamic Centre}

The Belfast Islamic centre is a Victorian styled semi-detached house, with a Mosque space on the first floor. The Mosque is the combination of three bedrooms (figure 14). The expectations of an Islamic centre seemed to be an amalgamation of considerations for Christian and Jewish buildings. No defined building form was identified however the majority of the youth did present a building with spires or pointed towers, with a bell and a cross. Some young people identified the worshippers as people wearing floor length gowns and using mats (figure 15).

During the visit the teenagers noted that the Islamic centre space was quite simplistic with only a bookcase and a few images on the walls. All young people identified the niche as the most important element within the space. They conveyed all the key elements including the bookcases, and prayer mat, microphone, clock and Arabic text (figure 16). 


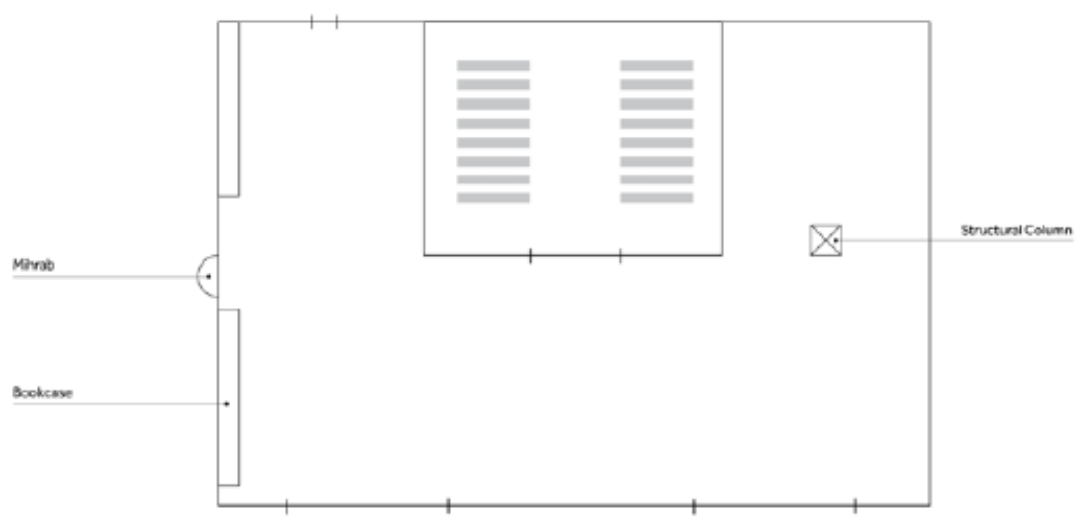

Figure 14: Spatial Representation of Islamic Centre

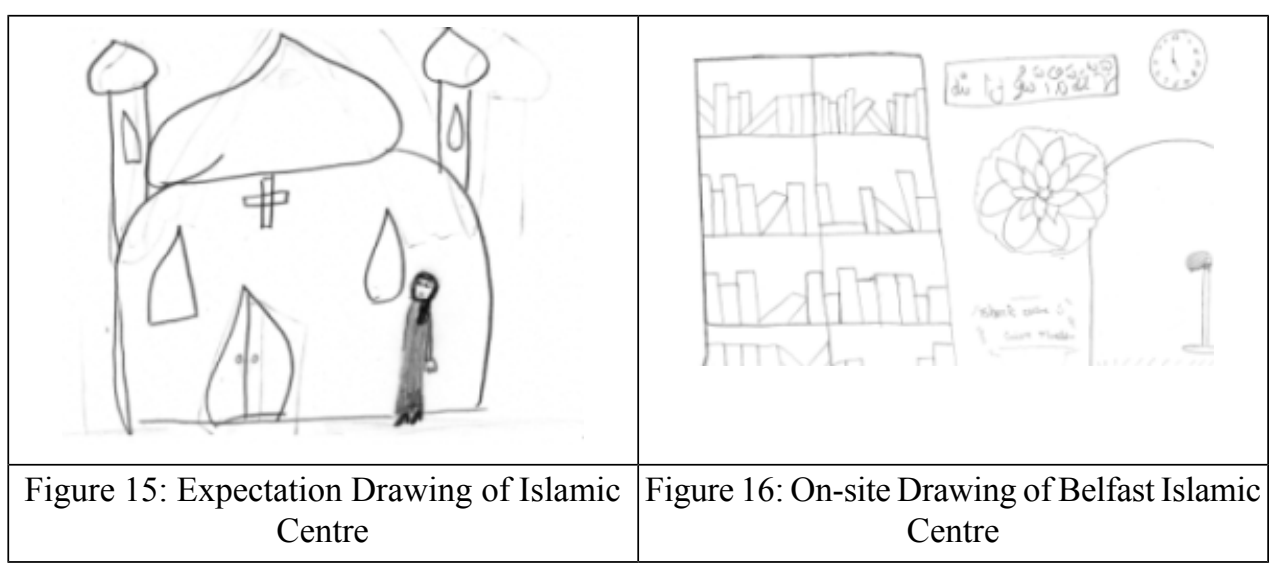

For the responsive session, the majority of young people used a basic rectangular form to outline the space in the Islamic centre. Some added another room on to the side to reflect the U shaped space. All noticed the alcove with the microphone and bookshelves with some noting the Islamic text on the walls. The pattern on the carpet was also conveyed in a number of drawings as prayer mats. The majority of the youth generally envisaged men and women to be allowed to use the same space but at differing times. The bookcases were consistently highlighted in yellow as areas of importance. The alcove was highlighted as the area in which the worshippers faced and in which people could not stand (figure 17). 


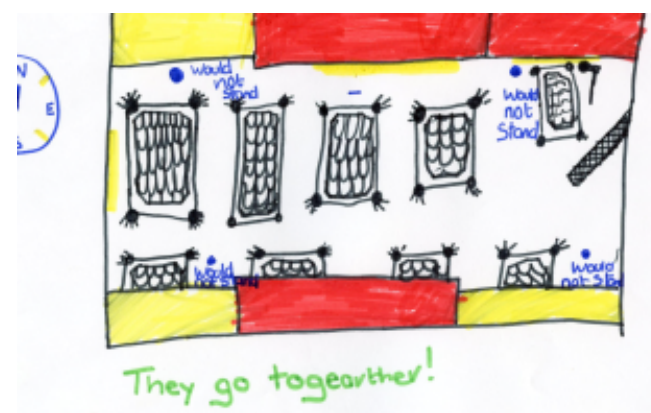

Figure 17: Youth Reflection Drawing of Belfast Islamic Centre

\section{Discussion and Conclusions}

This study produced a wealth of drawings, photographs and observation based notes, all of which provided some illustration, insight and understanding into the participant's perceptions of local religions and associated religious space. Limitations to the study included the small number of participants and the lack of information available on their cultural background. This restricted reliable comparisons on the social and cultural differences between teenagers of conflicting religions. However, despite the limited number of participants interesting findings and observations can still be reported.

\section{Spatial Perception of Religious Architecture}

In terms of religious architecture and spatial perception, the research has demonstrated that the teenagers involved in the project, had the clear ability to negotiate and interpret religious space. The studies suggests that teenage youth can provide an outline of experienced worship space and identify the areas and objects of importance both from observation and from memory. Interestingly, the study showed that the youths tended to be overwhelmed by the objects in the space and as a result disregarded the form of architecture and the buildings original purpose and denomination. The composition or form of the space did not appear to be relevant in any of drawings; however, the majority of young people developed and defined each space through a systematic reflection on objects, text and symbology. Overall, they also appeared to adopt natural drawing techniques relatively typical of their age range; using single lines and simplistic plan views. The external space or facade of each building or indeed the buildings location did not seem to be of any significance to the young people, with the exception of using it as a natural way of describing the building. They utilised the basic elements (walls, windows, doors and roofs - i.e. arche-types) to demonstrate their expectations. Basic geometrical primitives for example squares and circles were used.

\section{Architectural Concepts}

The young people were influenced by a number of architectural concepts identified at the early stages of the project. The youth recognised and responded to these established archi- 
tectural concepts by demonstrating an ability to compare and contrast spaces, despite their varied nature in shape, form and content. In terms of hierarchy of space it was found that the Christian teenagers were influenced by the structured, authoritarian spatial design of a church. The spatial pattern of each church inherently determined the behaviour and physical movement of the teenage youth. As a result, the young people from both the Protestant and Roman Catholic background were found to be more cautious about entering and exploring unfamiliar religious spaces such as the Synagogue, Temple and Islamic centre. They also displayed a knowledge or tolerance that there are certain spaces in religious buildings which should be respected. Contrastingly, the Hindu youths who appeared to be naturally used to a less structured spatial system of worship felt free to explore each space and ask open questions during the workshop. The study observed that the youth from the Christian faiths were more hesitant in terms of movement and that they waited to be led in and around the space. It was also noted that questions asked were in direct comparisons to their own faith, with many teenagers adopting an 'us' and 'them' attitude, seemingly using the exploration process to reinforce their own sense of identity.

Purity was another issue of interest although it was poorly represented in the drawings. The separation of men and women caused major issues among the young people from the Roman Catholic and Protestant groups. Issues of sexism against women were raised along with concerns over same-sex attraction. However, it was felt that the young people's upbringing, friendship groups and age were related to these concerns more so than religious identity. It was also noted during the study that protestant youth had no visible preparation for worship and this was reflected in their behaviour in each of the worship spaces and within their drawings.

With reference to orientation it was found that the shape or form of the spaces wasn't necessarily important but the directionality of the space was. The Roman Catholic and Protestant youth, who expected to be led in worship, found it difficult to comprehend disparity to the typical order of space. This confusion mainly occurred in the synagogue where the central platform and Torah platform could both be utilised to lead worship, therefore leading to questions over directionality. Also of interest was the lack of concern about the positioning of the Islamic prayer space on the first floor. The youth did not comment on the location or the orientation of the prayer room but choose to focus on the Mihrab and the direction of the pattern on the carpet.

\section{Understanding of Religion}

In terms of the youths perceptions, ideas and understanding of religion, the study showed that the youth involved had well defined religious identities, particularly the Roman Catholic and Protestant young people. The teenagers appeared to use their own religious identity as a means of understanding and negotiating religious space. The spaces were used more as a tool to reinforce their own systems of worship rather than to necessarily understand other faiths. Educational background and maturity also seemed to play a role in their tolerance to other religious cultures, however this aspect needs to be explored further in future research. The findings would suggest that the youth play a significant role in shaping their own experiences even within similar physical and social environments. This could be attributed to aspects of religious socialization as described by Mazumdar and Mazumdar (2004). 
In line with the work of Trew (2004) it has been seen that the separation of the two main religious backgrounds; Protestant and Catholic groups, has ensured that the religious views of young people are shaped by a collective; those of the same religion, rather than through experience and direct involvement with those from other religious backgrounds. Particularly, in attempting to understand the spaces, the young people used the process of assimilation to make sense of what they were experiencing. This study highlighted the difficulty still facing the separation of religion, politics and identity in Northern Ireland.

The study also showed that the young people were apprehensive about entering an unfamiliar religious building and this tended to manifest itself through concerns raised at the entrance to each building. Overall the project also highlighted a definite lack of knowledge regarding other religions and a disinterest in architecture. This was particularly evident from the Roman Catholic and Protestant groups. One of the key questions that emerged from this study related to the level of awareness of young people in Northern Ireland to minority religions.

In essence, findings would suggest that spatial experience of architecture can be used as a tool to help explore and remove the anxieties that surround religious identities especially in contested spaces such as Northern Ireland. Further studies incorporating a wider range of participants and utilising a similar methodological approach could help promote the cross cultural understanding of young people's perceptions of religion in tensioned societies. The cultural and social backgrounds of participants would need to play a larger role in future studies to enable more detailed conclusions.

Religious spaces are clearly important to young people in Northern Ireland and ultimately become an extension of their identity, but their relationships appears to lie with objects and symbols as opposed to architectural elements. By exploring this concept further and allowing young people to experience and comprehend alterative spaces, symbols and spatial patterns, they could become more visually connected and appreciative of their environment and local architecture.

\section{References}

Ashworth, J \& Farthing, I., 2007. Church going in the UK: A report from Tearfund on church attendance in the UK. Tearfund Publications.

Bachelard, G., 1969. The Poetics of Space., trans. Maria Jolas. Boston: Beacon Press.

Benson, P. L., Roehlkepartain, E. C., and Rude, S. P., 2003. "Spiritual Development in Childhood and Adolescence: Toward a Field of Inquiry.” Applied Developmental Science, 7(3), pp. 204-212.

Brown, B.B., and Perkins, D.D., 1992. Disruptions in place attachment. In I. Altman \& S. Low (Eds.), Place attachment (pp. 279-304). New York: Plenum.

Butterworth, G., 1977. The Child's Representation of the World. New York: Plenum Publishing Corporation.

Cairns, E.,1987. Caught in crossfire. Children in Northern Ireland. Appletree Press and Syracuse University Press.

Cairns, E., and Hewstone, M., 2002. Northern Ireland: The impact of peacemaking in Northern Ireland on intergroup behaviour. In G. Salomon \& B. Nevo (Eds.), Peace education: The concept, principles and practices around the world (pp. 217-228) Lawrence Erlbaum Associates.

Connolly, P., 2003. The development of young children ethnic identities: implications for early years in practice. In C. Vicent (Ed); Social Justice, education and identity ( pp. 166-184). London: Routledge. 
Connolly, P., and Healy, J., 2003. The development of children's attitudes towards "the Troubles" in Northern Ireland. In O. Hargie \& D. Dickson (Eds.), Researching the Troubles: Social science perspectives on the Northern Ireland conflict (pp. 37-58) Mainstream.

Connolly, P., Smith, A., and Kelly, B., 2002. Too young to notice? The cultural and political awareness of 3-6 year olds in Northern Ireland. Belfast: Northern Ireland Community Relations Council.

Donahue, M. J., and Benson P. L., 1995. Religion and the well-being of adolescents. Journal of Social Issues, 51(2), 145-160.

Erikson, E.H., 1968. Identity, youth and crisis. New York: W. W. Norton Company.

Furrow, J. L., King, P. E., and White, K., 2004. Religion and positive youth development: Identity, meaning, and prosocial concerns. Applied Developmental Science, 8, 17-26.

Foucault, M., 1972. The Archaeology of Knowledge and the Discourse on Language, trans. Pantheon, New York.

Kerestes, M., and Youniss, J., 2003. Rediscovering the importance of religion in adolescent development. In R. M. Lerner, F. Jacobs, \& D. Wertlieb (Eds.), Handbook of applied developmental science: Promoting positive child, adolescent, and family development through research, policies, and programs (Vol. 1, pp. 165-184). Thousand Oaks, CA: Sage.

Kieckhefer, R., 2004. Theology in Stone: Church Architecture from Byzantium to Berkley. Oxford University Press, USA.

King, P. B., 2003. 'Religion and Identity: The Role of Ideological, Social, and Spiritual Contexts', Applied Developmental Science, 7: 3, $197-204$.

Kitahara, R., and Matsuishi, T., 2006. Research on children's drawings. Journal of Disability and Medico-pedagogy, Journal of Disability, Medicine and Education, 14.

Korpela, K., Kytta, M; and Hartig, T., 2002. Restorative experience, self regulation and children's place preferences. Journal of environmental psychology 22 387-398.

Lerner, R. M., Dowling, E. M., and Anderson, P. M., 2003. Positive youth development: Thriving as the basis of personhood and civil society. Applied Developmental Science, 7, 171-179.

Malinowski, J.C. and Thurber, C.A., 1996. Developmental shifts in the place preferences of boys aged 8-16 years. Journal of environmental psychology, 16, 45-54

Matthews, M.H., 1995. Living on the edge: Children as outsiders. Tijdschrift voor Economische En Sociale Geografie, 86, 456-466.

Mazumdar, S and Mazumdar, S., 2004. Religion and place attachment: A study of sacred places. Journal of environmental psychology 24 (2004) 385-397.

Mitchell, C., 2006. Religion, Identity and Politics in Northern Ireland: Boundaries of Belonging and Belief. Ashgate Publishing Limited, London.

Norberg-Schulz, C., 1972. Existence, Space and Architecture. Praeger, New York.

Russell, D., 2004. Belfast: Strategies for a Shared City: Shared Space. A Research Journal on Peace Conflict and Community Relations in Northern Ireland. Published by Community Relations Council.

Sanoff, H., 2000. A Visioning Process for Designing Responsive Schools. AIA, School of Architecture, College of Design, North Carolina State University with support from the National Clearinghouse for Educational Facilities.

Trew, K., 2004. Children and Socio-Cultural Divisions in Northern Ireland. Journal of Social Issues.

Vale, L.J., 1999. Mediated monuments and national identity. The Journal of Architecture, 4: 4, 391408.

Wagener, L. M., Furrow, J. L., Ebstyne King, P., Leffert, N., and Benson, P., 2003. Religious involvement and developmental resources in youth. Review of Religious Research, 44(3), 271-28 


\section{About the Authors}

Dr. Karen McPhillips

My current research relates to the areas of architecture, cultural identity, political tensions and environmental behaviour in young people. In particular, my research considers the perceptions of landmark architectural forms and spaces in an attempt to understand behavioural responses. My research is primarily focused on tensioned societies such as Northern Ireland.

\section{Dr. Jenny Russell}

My principle research interest lies in the nature of design as a response to human need and human nature, in particular, the spatial comprehension of children and the influence that architecture can have on their behaviour. My particular concern lies with children's perceptions of space and makes investigations into how their perceptions compare with those of adults. 


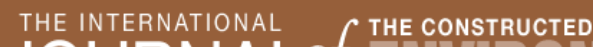 \\ JOURNAL of ENINRODNMENT}

\section{Editors}

Jeffery S. Poss, FAIA, School of Architecture, University of Illinois at UrbanaChampaign, USA

Bill Cope, College of Education, University of Illinois at Urbana-Champaign, USA

\section{Editorial Advisory Board}

Kathryn H. Anthony, School of Architecture, University of Illinois at UrbanaChampaign, USA.

Naima Chabbi-Chemrouk, Ecole Polytechnique d'Architecture et d'Urbanisme, Algiers, Algeria.

Bill Cope, College of Education, University of Illinois at Urbana-Champaign, USA.

Jeffery S. Poss, FAIA, School of Architecture, University of Illinois at UrbanaChampaign, USA.

Ryan E. Smith, College of Architecture and Planning, University of Utah, Salt Lake City, USA.

Please visit the Journal website at http://www.ConstructedEnvironment.com for further information about the Journal or to subscribe. 


\section{The Constructed Environment Community}

This knowledge community is brought together around a common shared interest in the role of the Constructed Environment. The community interacts through an innovative, annual face-to-face conference, as well as year-round virtual relationships in a weblog, peer reviewed journal and book imprint - exploring the affordances of the new digital media.

\section{Conference}

Members of the Constructed Environment Community meet at The International Conference on the Constructed Environment, held annually in different locations around the world.

In 2010 the Conference was held at Venice, Italy and in 2011 the Conference will be held at University Center in Chicago, USA.

Online presentations can be viewed on YouTube.

\section{Publishing}

The Constructed Environment Community enables members to publish through three media. First by participating in the Constructed Environment Conference, community members can enter a world of journal publication unlike the traditional academic publishing forums - a result of the responsive, non-hierarchical and constructive nature of the peer review process. The International Journal of the Constructed Environment provides a framework for double-blind peer review, enabling authors to publish into an academic journal of the highest standard.

The second publication medium is through the book series The Constructed Environment, publishing cutting edge books in print and electronic formats. Publication proposal and manuscript submissions are welcome.

The third major publishing medium is our news blog, constantly publishing short news updates from the Constructed Environment Community, as well as major developments in the various disciplines of the constructed environment. You can also join this conversation at Facebook and Twitter or subscribe to our email Newsletter. 


\section{Common Ground Publishing Journals}

\begin{tabular}{|c|c|}
\hline $\begin{array}{l}\text { AGING } \\
\text { Aging and Society: An Interdisciplinary Journal } \\
\text { Website: http://AgingAndSociety.com/journal/ }\end{array}$ & $\begin{array}{c}\text { ARTS } \\
\text { The International Journal of the Arts in Society. } \\
\text { Website: www.Arts-Journal.com }\end{array}$ \\
\hline $\begin{array}{c}\text { BOOK } \\
\text { The International Journal of the Book } \\
\text { Website: www.Book-Journal.com }\end{array}$ & $\begin{array}{c}\text { CLIMATE CHANGE } \\
\text { The International Journal of Climate Change: } \\
\text { Impacts and Responses } \\
\text { Website: www.Climate-Journal.com }\end{array}$ \\
\hline $\begin{array}{c}\text { CONSTRUCTED ENVIRONMENT } \\
\text { The International Journal of the } \\
\text { Constructed Environment } \\
\text { Website: www.ConstructedEnvironment.com/journal }\end{array}$ & $\begin{array}{c}\text { DESIGN } \\
\text { Design Principles and Practices: } \\
\text { An International Journal } \\
\text { Website: www.Design-Journal.com }\end{array}$ \\
\hline $\begin{array}{c}\text { DIVERSITY } \\
\text { The International Journal of Diversity in } \\
\text { Organizations, Communities and Nations } \\
\text { Website: www.Diversity-Journal.com }\end{array}$ & $\begin{array}{l}\text { FOOD } \\
\text { Food Studies: An Interdisciplinary Journal } \\
\text { Website: http://Food-Studies.com/journal/ }\end{array}$ \\
\hline $\begin{array}{c}\text { GLOBAL STUDIES } \\
\text { The Global Studies Journal } \\
\text { Website: www.GlobalStudiesJournal.com }\end{array}$ & $\begin{array}{c}\text { HEALTH } \\
\text { The International Journal of Health, } \\
\text { Wellness and Society } \\
\text { Website: www.HealthandSociety.com/journal }\end{array}$ \\
\hline $\begin{array}{c}\text { HUMANITIES } \\
\text { The International Journal of the Humanities } \\
\text { Website: www. Humanities-Journal.com }\end{array}$ & $\begin{array}{c}\text { IMAGE } \\
\text { The International Journal of the Image } \\
\text { Website: www.Onthelmage.com/journal }\end{array}$ \\
\hline $\begin{array}{l}\text { LEARNING } \\
\text { The International Journal of Learning. } \\
\text { Website: www.Learning-Journal.com }\end{array}$ & $\begin{array}{c}\text { MANAGEMENT } \\
\text { The International Journal of Knowledge, } \\
\text { Culture and Change Management. } \\
\text { Website: www.Management-Journal.com }\end{array}$ \\
\hline $\begin{array}{c}\text { MUSEUM } \\
\text { The International Journal of the Inclusive Museum } \\
\text { Website: www.Museum-Journal.com }\end{array}$ & $\begin{array}{c}\text { RELIGION AND SPIRITUALITY } \\
\text { The International Journal of Religion and } \\
\text { Spirituality in Society } \\
\text { Website: www.Religion-Journal.com }\end{array}$ \\
\hline $\begin{array}{c}\text { SCIENCE IN SOCIETY } \\
\text { The International Journal of Science in Society } \\
\text { Website: www.ScienceinSocietyJournal.com }\end{array}$ & $\begin{array}{c}\text { SOCIAL SCIENCES } \\
\text { The International Journal of Interdisciplinary } \\
\text { Social Sciences } \\
\text { Website: www.SocialSciences-Journal.com }\end{array}$ \\
\hline $\begin{array}{c}\text { SPACES AND FLOWS } \\
\text { Spaces and Flows: An International Journal of } \\
\text { Urban and ExtraUrban Studies } \\
\text { Website: www.SpacesJournal.com }\end{array}$ & $\begin{array}{c}\text { SPORT AND SOCIETY } \\
\text { The International Journal of Sport and Society } \\
\text { Website: www.sportandsociety.com/journal }\end{array}$ \\
\hline $\begin{array}{c}\text { SUSTAINABILITY } \\
\text { The International Journal of Environmental, Cultural, } \\
\text { Economic and Social Sustainability } \\
\text { Website: www.Sustainability-Journal.com }\end{array}$ & $\begin{array}{c}\text { TECHNOLOGY } \\
\text { The International Journal of Technology, } \\
\text { Knowledge and Society } \\
\text { Website: www.Technology-Journal.com }\end{array}$ \\
\hline $\begin{array}{c}\text { UBIQUITOUS LEARNING } \\
\text { Ubiquitous Learning: An International Journal } \\
\text { Website: www.ubi-learn.com/journal/ }\end{array}$ & $\begin{array}{l}\text { UNIVERSITIES } \\
\text { Journal of the World Universities Forum } \\
\text { Website: www.Universities-Journal.com }\end{array}$ \\
\hline
\end{tabular}

